\title{
COMPARATIVE ANALYSIS OF NIZAMI GANJAVI'S EPICS “MAKHZAN UL-ASROR” AND ALISHER NAVOI'S “HAYRAT UL-ABROR”
}

\author{
Mamura Khayrullaevna Rashidova
}

Candidate of Philological Sciences, Academy Of Sciences of The Republic Of Uzbekistan Alisher Navoi State Museum Of Literature, Uzbekistan

\section{ABSTRACT}

The first works of the series of epics "Khamsa" by the great thinkers Nizami Ganjavi and Alisher Navoi are called "Makhzan ul-Asror" and Hayrat ul-Abror ". Both epics are on a philosophical-ethical theme, reflecting the social views of the great scholar-poets. "Makhzan ul-Asror" is written in Persian, and "Hayrat ul-Abror" is written in Turkish. Although these works are ideologically complementary, they are by no means a repetition of each other. A comparative analysis of both epics highlights the uniqueness of the method of expression, the different attitudes to events and happenings, and the importance of the variety of exemplary stories.

KEYWORDS: - Khamsa, praise, description, prayer, salawat, article, story.

\section{INTRODUCTION}

Jamaliddin Abu Muhammad Ilyas bin Zaki bin Abulmuayyad, that is, Nizami Ganjavi is a great poet and thinker who wrote the first "Khamsa" in the poetry of the East - a series of five epics and founded the school of Hamsanavism. The people of Adab call him Hakim Nizami. He is known as Nizami Ganjavi. In Persian literature, Khusrav Dehlavi and Abdurahman Jami are the artists who followed Nizami in creating "Khamsa". In response, the great poet and thinker Alisher Navoi wrote his "Khamsa" in Turkish. He acknowledges the great potential of the master poet, saying, "It is not easy to stand in this field, to claw Nizami's paw". Alisher Navoi also describes the poet with deep respect and reverence in almost all his works, especially in every epic of "Khamsa", "Nasoim ul Muhabbat".

Alisher Navoi dedicates the twelfth chapter of the epic "Hayrat ul-Abror" in praise of Sheikh Nizami and Amir Khusrav Dehlavi. In the next chapter, Abdurahman Jami is described. It is narrated that between the teacher Jami and Navoi, "Nizami and Khusrav are discussed [1, p. 12]. What excitement did not come to the world of the two "Khamsa" created by their pen! But out of these ten beautiful epics included in the two "Khamsa", the first two stood out. In response to these two friends, 
CURRENT RESEARCH JOURNAL OF PHILOLOGICAL SCIENCES 2(12):

95-98, December 2021

DOI: https://doi.org/10.37547/philological-crjps-02-12-20

ISSN 2767-3758

(C)2021 Master Journals

Crossref do

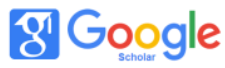

Accepted14 ${ }^{\text {th }}$ December, 2021 \& Published 19th December, 2021

Abdurahman Jami wrote "Tuhfat ul-Ahror" [1, p. 12]. "He stood royal from beginning to end". Impressed and inspired by Alisher Navoi, they all followed this path, so what if I took a few steps? After all, they wrote their works in Persian, and I will start with Turkish.

Yo'llasa, bu yo'lda Nizomiy yo'lum, Qo'llasa, Xusrav bila Jomiy qo'lum ... hoping to start writing the epic "Hayrat ul-Abror". Navoi writes in the hymn of Sheikh Nizami, who won five treasures consisting of cash gold and pearls with his precious paws in the property of poetry...

He is the crown on the heads of word artists, even the jewel of that crown whose value is equal to a treasure. He can be called the guardian of the pearls in the mine of virtue [1, p. 9], the precious pearl of the river of perfection.

"Makhzan ul-Asror" ("Treasure of Secrets") is the first epic of Nizami Ganjavi's "Khamsa". According to the author, the writing was completed on September 30, 1176, according to the melodic account, in the month of Rabe'ul $24 \mathrm{AH}, 572 \mathrm{AH}$.

The text of the epic "Makhzan ul-Asror" was published in 1984 in Dushanbe, "Irfon" publishing house. It is stated in the introductory part of the collection that it was written in response to Sanayi Ghaznavi's "Hadiqat ul-Haqiqat" [2]. Before this epic was written, Nizami was famous for his Gazelle. The work "Makhzan ul-Asror", which has a moral, philosophical and educational significance, has also aroused the interest of many.

Comparing the contents of Nizami Ganjavi's "Makhzan ul-Asror" and Alisher Navoi's "Hayrat ulAbror", we see that both epics traditionally begin with an introduction and a prayer, but they differ greatly both in structure and in style. . While Nizami's epic consists of one introductory part, in Navoi this chapter consists of two parts. While
Nizami's prayer consists of two chapters, Navoi's prayer consists of four parts. After two prayers, Nizami wrote two chapters, "In the Name of the Noble Messenger" and "In Me'raj" " He then brings four salawat. Navoi, on the other hand, writes a fivepart note after the prayers. The next six chapters are devoted to the descriptions of Hazrat Sheikh Nizami and Amir Khusraw, Nuriddin Abdurahman Jami, the definition of words, the power of words, Sultan Abulgazi Husayn Bahodirkhan and the heart. This is followed by three chapters on three wonders. The next chapter describes Hoja Bahauddin Naqshband. We conditionally define these chapters as the first part of the work. Because then comes the second, main part - twenty articles and so many stories.

Fakhruddin Bahromshah ibn Dawud madhida; The call is said on the ground floor; This letter is in status and career; Statement of word quality; The advantage of the word manzum over Mansur; In the description of the night and the understanding of the soul; In the care of the tongue before seclusion; samarayi xilvati avval; The second solitude is at night; The fruit of the second desolation.

The first part of the epics of both thinkers is thus composed in such a peculiar way. The conditionally second parts of both epics consist of twenty articles and as many stories. These articles and stories, which have the same number in number, are radically different from each other in terms of subject matter and meaning. Although the views of both thinkers on religion and faith, the world and man, the word and the soul, society and individual life, etiquette and morality are close to each other, they are unique in their method of expression, in quoting exemplary stories and in drawing conclusions.

Aziz Qayumov's work on the first epic of Alisher Navoi's "Khamsa" "Hayrat ul-Abror" provides 
CURRENT RESEARCH JOURNAL OF PHILOLOGICAL SCIENCES 2(12):

95-98, December 2021

DOI: https://doi.org/10.37547/philological-crjps-02-12-20

ISSN 2767-3758

(C)2021 Master Journals

Crossref do

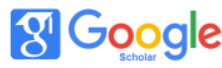

Accepted14 ${ }^{\text {th }}$ December, 2021 \& Published 19th December, 2021

detailed information about all major studies on this epic and their performers [3, pp. 6-10].

The academician also gives a detailed account of the ideological and artistic content of "Hayrat ul-Abror". It can be seen that a lot of scientific research has been done on "Hayrat ul-abror". Our goal is to study the epic "Makhzan ul-Asror" by Nizami Ganjavi, who was the first to write "Khamsa" before Navoi, and to compare it with "Hayrat ul-Abror". In this work, a new translation of "Makhzan ul-Asror" "Treasure of Secrets" and the research of academician Aziz Kayumov on the works of Alisher Navoi, Alisher Navoi's "Complete Collection of Works" from the seventh volume, "Hayrat ul-Abror". We made extensive use of Hayitmetov's prose statement.

Below, we will try to analyze both epics in more depth and show the traditional similarities and their differences from each other. The classical literature of the Middle East is inseparable from the teachings of Islam, Islamic thought. In Eastern epics, all works begin with the praise of God, the attributes of God, the oneness of God, and examples from the verses of the blessed verse.

Hakim Nizami Ganjavi was not only a great poet, but also a scholar of the Qur'an, a jurist and a scholar of tafsir. He was also fluent in Arabic, Greek, and ancient Pahlavi dialects, and embodied the wisdom of secular, religious, and spiritual treasures in his works. He traditionally begins his epics, including "Makhzan ul-Asrar", with the praise of Allah, and commits it in the name of Allah. The story begins, "Bismillohir-rahmonir-Rahim, hast kalidi dari ganji Hakim - In the name of God, Most Gracious, Most Merciful".

After describing the attributes of Allah one by one, Nizami cites two prayers. The first, before the prayer, is called "the wrath of Allah and the fear of Him". In the first prayer, Nizami supplicates to
Allah: 0 all beings, the heavens and the earth have arisen from your power, and you have produced all kinds of blessings. You even created Adam, our first ancestor, by digging in the mud! You placed his descendants on this land and provided them with food from the black soil. Indeed, you are the Sustainer of sustenance.

The first philosophical and educational epic of Alisher Navoi "Khamsa" "Hayrat ul-Abror" begins in accordance with the traditions of classical literature. "In the name of God, Most Gracious, Most Merciful", Navoi quotes the famous phrase from the Qur'an, the main book of Islam ("In the name of God, Most Gracious, Most Merciful"). After that, every letter of every word in this Arabic sentence was given a great meaning. According to Navoi, "Allah and His name are closely connected with the whole universe and beings. In this case, Navoi used the art of writing more as an artistic means of expressing his religious and philosophical views".

In the next four chapters, four prayers are expressed. In these prayers, Alisher Navoi describes the qualities of the Creator, emphasizing that $\mathrm{He}$ created this infinite being for man. The greatest and most honorable of all creatures is man

Both epics have twenty articles and as many stories. Although their content and essence are close to each other, they are not exactly repetitive. The thinkers carried out the task set before them with a special originality.

Nizami Ganjavi and Alisher Navoi are prominent, famous and respected scholars of their time. Both thinkers glorify in their works the man who is the most influential, the most honorable, the most intelligent and the most intelligent of all creatures. They encourage people to be friendly and appreciative of each other. The ideas of humanity and patriotism were clearly reflected in the works of both poets, who expressed their care and 
CURRENT RESEARCH JOURNAL OF PHILOLOGICAL SCIENCES 2(12):

95-98, December 2021

DOI: https://doi.org/10.37547/philological-crjps-02-12-20

ISSN 2767-3758

(C)2021 Master Journals

Crossref do

8 Google

Accepted14 ${ }^{\text {th }}$ December, 2021 \& Published 19th December, 2021

kindness to the people with great artistic power. It is especially characteristic of them to glorify attention, care, kindness, forgiveness, and justice to the people through the emblems of a just king, elevating justice.

While praising the king of his time, Malik Fakhruddin Bahromshah ibn Dawud, Nizami emphasizes that he was a ruler, a just ruler. Alisher Navoi praises Abulgazi Sultan Hussein Bahodirkhan. Stories about kings speak of their justice and nationalism.

In their works, Nizami and Navoi condemn the tyranny of kings and call on them to take care of the people. "Elu Yurt" emphasizes that the prosperity of the country is done for the sake of justice, doing justice.

All the good qualities inherent in a human being evoke strong feelings of friendship, brotherhood, affection, and affection between them. Such pure, unadulterated lovers will admire the beauties of the whole world with admiration, and they will be thankful for this life.

\section{Conclusion}

These beautiful feelings, which attracted a lot of attention of Nizami and Navoi, are also closely connected with the feeling of patriotism. The more Nizami Ganjavi glorifies his native Ganja, the more Navoi raises the heart of Khorasan to Herat. So, love for the people, the country, the country is the most noble feelings. Love for the motherland comes from gratitude for the land that sustains man and the blessings bestowed upon him. This leads to sincere service and devotion.
1. Alisher Navoi. "Hayratul-abror. ("Amazement of the good people") Prose narrator A. Hayitmetov. Gulom Publishing House of Literature and Art. - Tashkent. 1974. - p. 12.

2. Prof. E.E. Bertels expressed the same opinion. But the Azerbaijani literary critic objected to this idea. He believes that Nizami's Hamsa has nothing to do with Hakim Sanoi's epic. We will now limit ourselves to reporting these comments. Because the issue of Industry and Nizami is a big issue. It should be considered separately. M.R.

3. Aziz Qayumov. (2008) Works, Volume 1, Book 1. "Mumtoz Soz" Publishing House, Tashkent. - pp. 6-10.

4. Nizami Ganjavi. College. 5 Vols. Irfon Publishing House. Dushanbe, 1983-84.

5. Nizami Ganjavi. Hamsa. Translated from Persian by Olimjon Buriev. Tafakkur Kanoti Publishing House. Tashkent, 2016.

6. M. Rashidova. (2015) "Treasure of pearls", "Classic word".

\section{ReFERENCES}

